\title{
Effect of Contract Farming on the Income and Risk of Pistachio and Saffron Producers in Iran
}

\author{
Efeito do cultivo sob contrato na renda e no risco dos produtores de pistache e açafrão no Irã \\ Mohammad Mehri Abarghouei, Mahmoud Ahmadpour Borazjani, Hamid Mohammadi, Mashallah \\ Salarpour
}

University of Zabol, Zabol, Iran. *Author for correspondence: mahmadpour@uoz.ac.ir

Submission: 22/12/2019 / Acceptance: 06/03/2020

\begin{abstract}
Contract farming is among the institutional arrangements essential for agricultural products. In most cases, these contracts lead to increased incomes and welfare of farmers. However, this type of business has not been taken seriously in Iran. This study aimed to analyze the effect of contract farming on the income and risk of the farmer's income. To this end, pistachio and saffron farmers in the Yazd Province, in central Iran, were considered in the harvest year of 2017-2018. We divided the farmers into three homogeneous groups, each with different input consumption levels and production per hectare. We calibrated the cost functions of representative farmers in each group. These functions were employed to develop an ideal formal contract model and relational contract model. According to the results, formal contracts and relational contracts increased income and relational contracts reduced the risk to farmers when they were compatible with the incentive constraints of the farmer. Policymakers should provide favorable conditions for the development of contract farming. For instance, they can present contract farming to farmers and encourage agricultural enterprises to participate in contracts by facilitating access to credit and other investment incentives.
\end{abstract}

KEYWORDS: formal contract, relational contract, optimal contract, incentive constraint, Yazd Province JEL Classification: Q1, D4.

\section{RESUMO}

A agricultura por contrato está entre os arranjos institucionais mais essenciais para os produtos agrícolas. Esses contratos, na maioria dos casos, levam ao aumento da renda e do bem-estar dos agricultores. No entanto, esse tipo de negócio não foi levado a sério no Irã. Este estudo teve como objetivo analisar o efeito da agricultura contratual sobre a renda e o risco da renda do agricultor. Para esse fim, os produtores de pistache e açafrão na província de Yazd, no centro do Irã, foram considerados na safra 2017-2018. Os agricultores foram divididos em três grupos homogêneos, cada um com diferentes níveis de consumo de insumos e produtividade por hectare. Em seguida, as funções de custo dos agricultores representativos foram calibradas em cada grupo. Essas funções foram empregadas para desenvolver um modelo de contrato formal ideal e contrato relacional. De acordo com os resultados, contratos formais e contratos relacionais aumentaram a renda e os contratos relacionais reduziram o risco dos agricultores quando eles eram compatíveis com as restrições de incentivo do produtor e principal. Recomenda-se aos formuladores de políticas que forneçam condições favoráveis ao desenvolvimento da agricultura contratada. Por exemplo, eles podem familiarizar os agricultores com a agricultura contratual e incentivar as empresas agrícolas a participar de contratos, facilitando o acesso ao crédito e outros incentivos ao investimento.

PALAVRAS-CHAVE: contrato formal, contrato relacional, contrato ideal, restrição de incentivo, província de Yazd Classificação JEL: Q1, D4

\section{INTRODUCTION}

In recent decades, a tendency has begun in economics, reaching its maturity nowadays. This tendency, which is characterized by the contract theory or the economics of contracts, interprets human interactions with a contractual method for analyzing efficiency, incentives, income distribution, and many other concepts (LAFFONT \& MARTIMORT 2002). Along with other economic sectors, agricultural contracts 
have been widely developed (ABEBE et al. 2013). Product-sharing agreements between tenants and landlords formed the basis of agricultural economics in ancient times. A contract between a principal and a landlord farmer is an initiative that has emerged in the last 100 years (BARRETT et al. 2012). The firm can supply agricultural inputs or the required capital and provide the farmer with technical assistance if necessary. In return, the farmer sells his crop to the firm. In other words, contract farming is an agreement by which the farmer is committed to producing a certain amount of product at a specified price and the buyer is committed to buying that product (BARRETT 2008). These contracts apply to various types of crops and political and economic systems worldwide (DINA 1997, MINTEN et al. 2009). Contact farming plays a more active role in agricultural production of developing countries given the recent changes in the supply and demand of agricultural products in said countries, such as an increased per capita income, changing interests, liberalization of financial markets, and new standards of farm products (FAFCHAMPS 1992, LYSON 2012.

The low income of farmers is a severe challenge to agricultural products on the market. Agricultural production poses a significant risk to farmers. Furthermore, the unbalanced bargaining power on demand for farm products is in favor of major buyers and brokers in most cases, with farmers always achieve lower profits (WU 2006). Hence, many studies have surveyed the impact of contract farming on the income and risk of farmers (LITTLE \& WATTS 1994, PORTER \& PHILIPS-HOWARD 1997ab, SINGH 2002, REHBER 2007). The literature shows different results on the income and welfare level of farmers after contract farming. Some scholars concluded that participation in contract farming increases the income of farmers (WARNING \& KEY 2002, BARRETT et al. 2012, BELLEMARE 2012). However, the extent in which the participation in contract farming affects the welfare of farmers is still controversial (BARRETT et al. 2012). According to WARNING \& KEY (2002), MIYATA et al. (2009), and WANG et al. (2011), there is no evidence of the lack of increased welfare of small farmers in Senegal and China, respectively. However, SINGH (2002), GUO et al. (2005), and KEY \& RUNSTEN (1999) reported evidence of the inefficiency of contract farming in increasing the welfare of farmers in India, China, and Latin America, respectively. Other studies have even reported a decline in the farmers' welfare. According to the literature, in cases where contract farming has led to an increase in the farmers' income, the parties have had an incentive to respect the provisions of the agreement. In other words, the agreement determines the production and price in such a way that farmers with different characteristics are willing to participate in the contract. There are also incentives for maximum efforts by farmers (LITTLE \& WATTS 1994, BIJMAN et al. 2016).

LAFFONT \& MARTIMORT (2002) and DEWATRIPONT \& BOLTON (2005) have evaluated contracts in terms of efficiency, incentives, and information. They have introduced optimal contracts and analyzed their effects. However, the design of contract farming for the maximum participation of farmers has received little emphasis (WU 2014). Thus, a closer look at contract farming may provide more details on the design of incentive-compatible contracts. Therefore, the proper design of contract farming and its effects on the farmers are essential for policymakers because the reduction in the farmers' income can lead to an increase in rural-to-urban migration and a decrease in the supply of food products (SWINNEN \& MAERTENS 2007). Contract farming has received little emphasis in Iran from the academic and policymaking perspectives. There is also evidence of a low and unsustainable income of farmers. Hence, the inability of farmers in meeting their basic needs has led to an increase in rural-to-urban migration. According to the STATISTICAL CENTER OF IRAN (2018), the migration rate from rural to urban areas in the Yazd Province in 2017 shows $25 \%$ growth when compared to 2007. Therefore, analysts and policymakers should look for a solution to increase farmers' incomes which is important from two perspectives. First, increasing farmers' income will prevent them from migrating to urban areas. Second, it will avoid the reduced supply of farm products, given that more than $34 \%$ of agricultural products are produced by rural communities in Iran (IRAN MINISTRY OF AGRICULTURE JIHAD 2017).

This study aimed to design optimal incentive-compatible contracts to increase farmers' income. More information on optimal contract farming can be used in agribusinesses to create arrangements and can help policymakers to develop an institutional environment. To this end, the essential characteristics of contract farming were first discussed to model optimal contracts. Subsequently, using data collected from the farmers, the price and production suggested by the optimal contract and their effects on farmers' income were analyzed. Finally, we evaluated the risk of farmers before and after their participation in contract farming. 


\section{MATERIAL AND METHODS}

\section{Important Characteristics of Contract Farming}

According to the literature of contract farming, most contracts contain provisions which accurately determine the quality of the product. However, there is no guideline on the other commitments of the parties to the agreement. Particularly, contract designers neglect quantity commitments such as production and delivery schedule, the volume purchased by the contractor (agribusiness firms), the amount produced by the farmer (in production contracts), and annual changes in the quantity, which may be described only in general (LAJILI et al. 1997, KIRSTEN \& SARTORIUS 2002). This leads to ambiguity because the quantity of the product sold at a given time, as its quality, is vital in determining the farmer's income and the costs of an agricultural firm (KOVÁCS 2018).

Even when a contract is complete with more details than other arrangements, the absence of a third party to review and monitor the agreement will limit its implementation. Despite the role of a third party such as a court, it is difficult to detect the deviation of parties from an agreement which leads to a discretionary latitude from parties to deal with those deviations (WU 2014). Another characteristic of contract farming is the repeatable nature of such contracts. For instance, over $90 \%$ of current tomato production contracts in California are extended by farmers to the subsequent year (WU \& ROE 2007). According to game theory, repeated trades are useful for reducing inefficiencies in one-shot games such as the prisoner's dilemma. Since relational contracts are like a sequential prisoner's dilemma game, an ex-post discretionary latitude can be organized concerning repeat trading to achieve an intuitive way to explain the incompleteness of contracts (LEEGOMONCHAI \& VUKINA 2005).

The fact that most contract farming is incomplete relational contracts implies ex-post discretionary characteristics of at least one of the parties. For instance, most agreements for the purchase of agricultural goods are conducted verbally by handshaking or over the telephone. Therefore, there is the possibility of diversion of each party from the upfront agreement. In other words, the parties must learn how to manage the counterparty risk. The counterparty risk means that one of the parties does not fully comply with the agreements. This risk is real and comprehensive in agricultural businesses (MURRAY 2014). Nevertheless, the classic contract theory emphasizes conflicts between risk and incentives (WU \& ROE 2007). In general, the incompleteness of contract farming, repetitive contracts, and the counterparty risk are some of the firstorder characteristics of contract farming.

\section{Modeling of First-Order Characteristics}

In this section, we developed a model to include some of the first-order characteristics of contract farming, such as their incompleteness and repetitive nature. WU (2014) was the first to use this model. Based on the results obtained by HALAC (2012), LEVIN (2003), and MACLEOD (2007) on contract design, a more flexible model was designed to consider the discretionary and repetitive nature of contracts.

The model starts with a principal (e.g., an agricultural firm) who contracts with an agent (e.g., a farmer) to produce a certain amount of a crop. As discussed earlier, a contract is an agreement to be executed. There are a few enforcement limits in any business negotiation that may leave at least one party with discretionary latitude to deviate from the upfront agreement (WU 2014).

Under a contract, each party has obligations to take actions consistent with the agreement. The action taken by the principal and the farmer (agent) is $a_{i} \in A_{i}$ where $i=A, P$, A is the farmer (agent) and $\mathrm{P}$ is the principal (DEWATRIPONT \& BOLTON 2005).

Also, $\mathrm{P}$ and $\mathrm{B}$ are the base price and the fixed bonus determined by the contract. The payoff functions for the principal and agent are defined as $\pi_{P}=r(q)-p-b$ and $\pi_{A}=p+b-c(q)$, respectively, where $r^{\prime}>0, r^{\prime \prime} \leq 0, c^{\prime}>0$, and $c^{\prime \prime} \geq 0$. The principal always prefers a larger production, whereas agents prefer higher payments.

We assumed that there are only three types of production technology for the product, $A_{A}=\{l o w$, medium, high $\}$ including low technology or production with the lowest efficiency, medium efficiency, and the highest efficient technology, respectively.

An example of a perfect enforcement technology is given by

$E_{A}=\left\{e_{A 1}, e_{A 2}, e_{A 3}\right\}=\{\{$ low $\},\{$ medium $\},\{$ high $\}\}$. Each element should be defined so that a third party will 
be able to distinguish the production. However, a technology characterized by $E_{A}=\left\{e_{A 1}, e_{A 2}\right\}=\{\{$ low $\},\{$ medium, high $\}\}$ is imperfect, because a third party can determine when a low supply occurs without recognizing medium and high volume. Therefore, the contractible set is defined as $\underline{E_{A}}=\left\{\underline{e_{A 1}}, \underline{e_{A 2}}\right\}=\{$ low, medium $\}$. If $E_{A}=\left\{e_{A 1}\right\}=\{\{$ low, medium, high $\}\}$, only inefficient production technology is identified by the court (the court can only identify the inefficient production technology) (ibid).

The contract execution method in the previous section provides a precise way of defining an incomplete contract. Considering the execution as mentioned above, $E_{A}=\left\{e_{A 1}, e_{A 2}, e_{A 3}\right\}=\{\{$ low $\},\{$ medium $\},\{$ high $\}\}$ a complete agreement can be written. A complete contract can be set to trade the efficient production $Q=$ high at a price $P$. Alternatively, it can determine an incomplete set of state-contingent prices $P_{l}, P_{m}$, and $P_{h}$, paid after observing each production without the principal demanding a specific level of production. In the first contract, a third party directly determines the prices $\mathrm{P}$ and production $\mathrm{Q}$. In the second contract, however, a third party enforces conditional payments $P_{l}$ , $P_{m}$, and $P_{h}$. Provided that the conditional payment method is chosen to ensure the incentive compatibility of production, both contracts have the same result of $Q=$ high (WU 2014).

\section{Optimal Contract}

As discussed earlier, when scheduling a contract, a principal (e.g., a pistachio processing company or a saffron packaging and exporting company) provides a list of intended production and price without any information on the type of farmers (agents). The agent (farmer) checks the list and selects a contractual option meeting the incentive compatibility and participation subjective constraints according to the revelation principle (LAFFONT \& TIROLE 1991). The principal proposes the contract list to maximize his utility. The model provided by HIDEO et al. (2012) was used in this study to analyze the formal contract. According to this model, the principal initially proposes a business negotiation which determines the quantity $x_{i}$ and the price $w_{i}$. The index i shows the type of agent that the principal suggests for the contract.

In the model proposed by HIDEO et al. (2012) for optimal contracts, $p_{i}$ is the probability that the principal faces with each type of farmer. As a result, we maximized the expected utility of the principal as follows:

$$
\max u t i l=\sum_{i} p_{i}\left[b\left(x_{i}\right)-w_{i}\right]
$$

s.t.

$$
\begin{aligned}
& b\left(x_{i}\right)=x_{i}^{0.5} \quad \forall i \\
& w_{i}-\theta_{i} x_{i} \geq r u \quad \forall i \\
& w_{i}-\theta_{i} x_{i} \geq w_{j}-\theta_{i} x_{j} \quad \forall i \neq j
\end{aligned}
$$

Accordingly, (3) and (4) show the participation and incentive compatibility constraints, respectively, and $\theta_{i}$ is the farmer's marginal cost when $\theta_{i} x_{i}$ is the marginal cost for producing the product unit $x_{i}$ by the farmer type $i$. To calibrate the cost function, we used the method presented by HOWITT (1995). According to HOWITT (1995), this function is calibrated precisely in line with the farmer's behavior in the base year. Therefore, it can simulate agricultural policies. Furthermore, ru represents the farmer reservation utility, which in this study is considered the farmer's net profit without contract farming.

The right-hand side of Constraint (3) represents the net profit. This constraint guarantees the higher net income of the farmer after participation in the contract when compared with the non-contractual state. Constraint (4) is the incentive compatibility guaranteeing that none of the farmer types will imitate another type. In other words, the contractual list provided to any farmer is preferable to that presented to different types (LAFFONT \& MARTIMORT 2002). This constraint was rewritten as follows: 


$$
\begin{aligned}
& w_{1}-\theta_{1} x_{1}-\frac{\gamma_{1} x_{1}{ }^{2}}{2} \geq w_{2}-\theta_{1} x_{2}-\frac{\gamma_{1} x_{2}{ }^{2}}{2} \\
& w_{2}-\theta_{2} x_{2}-\frac{\gamma_{2} x_{2}^{2}}{2} \geq w_{1}-\theta_{2} x_{1}-\frac{\gamma_{2} x_{1}{ }^{2}}{2}
\end{aligned}
$$

Constraints (5) and (6) guarantee that the farmer in the first group does not imitate the farmer in the second group and the farmer in the second group does not imitate the farmer in the first group. The contract proposed to any farmer must be in a way that he would prefer what is proposed instead of other proposals and does his best to produce according to the suggested price. We considered the above constraint for different types. This set of constraints are incentive-compatible constraints which guarantee farmer $i$ will obtain more profits after recognizing his/her type and choosing the contract $\left\{w_{i}, x_{i}\right\}$ in comparison with the case where he/she introduces his/her type incorrectly and selects the contract $\left\{w_{j}, x_{j}\right\}$. Thus, the farmer's knowledge of his type, or in other words, the use of inputs and production of a specific product becomes apparent to the principal. Upon contract, the farmer will deliver the product and receive his agreed remuneration.

The above contract is a formal one. An essential feature of contract farming is the incompleteness nature of such agreements leading to discretionary latitudes for contracting parties. Therefore, the modeling of relational contract, as an informal contract, is described to be consistent with the party incentives.

As discussed, contract farming is repeatable. Since contractual relations are considered a sequential prisoner's dilemma game, one can organize the discretionary latitude concerning repeat trading. To this end, WU (2014) developed a model in which payment to the farmer would include a fixed price $(P)$ plus a bonus (B) for better performance. This bonus will increase the farmer's efforts because he is trying to achieve a higher reward in addition to the fixed price by performing better agricultural operations.

For this purpose, we formulated the relational contract as follows:

$$
\max \left[r\left(Q_{i, P, B}\right)-P_{i}-B_{i}\right]+\frac{\left[r\left(Q_{i}\right)-P_{i}-B_{i}\right]}{\delta}
$$

s.t.

$$
\begin{aligned}
& {\left[r\left(Q_{i}\right)-P_{i}-B_{i}\right]+\frac{\left[r\left(Q_{i}\right)-P_{i}-B_{i}\right]}{\delta} \geq \alpha \pi_{f}+(1-\alpha) \bar{\pi}} \\
& {\left[P_{i}+B_{i}-c\left(Q_{i}\right)\right]+\frac{\left[P_{i}+B_{i}-c\left(Q_{i}\right)\right]}{\delta} \geq \alpha u_{i f}+(1-\alpha) \overline{u_{i}}} \\
& {\left[r\left(Q_{i}\right)-P_{i}-B_{i}\right]+\frac{\left[r\left(Q_{i}\right)-P_{i}-B_{i}\right]}{\delta} \geq\left[r\left(Q_{i}\right)-P_{i}\right]+\frac{\left[\alpha \pi_{f}+(1-\alpha) \bar{\pi}\right]}{\delta}} \\
& {\left[P_{i}+B_{i}-c\left(Q_{i}\right)\right]+\frac{\left[P_{i}+B_{i}-c\left(Q_{i}\right)\right]}{\delta} \geq\left[P_{i}-c\left(\overline{q_{i}}\right)\right]+\frac{\left[\alpha u_{i f}+(1-\alpha) \overline{u_{i}}\right]}{\delta}}
\end{aligned}
$$

The principal knows that he/she must propose the contract $(P, B, Q)$ in each period to meet the farmers' incentive compatibility and participation constraints. If these constraints are satisfied, the farmer accepts the offer. Hence, what the principal obtains from the contract after starting cooperation with farmer $i$ in each period is $r\left(Q_{i}\right)-P_{i}-B_{i}$. Therefore, its present value is equal to (OSKONEZHAD 1993):

$$
z=\frac{1+\delta}{\delta}\left[r\left(Q_{i}\right)-P_{i}-B_{i}\right]
$$

The principal must make offers to maximize the objective function $z$. 
The utility discount rate, $\delta$ is sometimes referred to as the rate of pure time preference. A positive $\delta$ implies impartiality. In other words, the farmer prefers to obtain the utility sooner. According to DASGUPTA \& HEAL (1980), the discount rate is not measured but chosen by the researcher. However, to determine a specific discount rate, the long-term interest rate on government bonds or the market interest rate will be equal to the utility discount rate (MARGLIN 1963).

Constraint (8) represents the principal's participation in the relational contract. In other words, the principal offers a relational contract when the utility or profit from this contract exceeds the utility of the formal contract $\pi_{f}$ or the utility outside of the contract $\bar{\pi}$ (reservation utility).

Constraint (9) refers to the farmer's participation in the relational contract. Farmer $i$ obtains $\left[P_{i}+B_{i}-c\left(Q_{i}\right)\right]_{\text {by }}$ participating in the relational contract in each period after the beginning of the partnership. Therefore, the present value of the farmer's profit was regarded as follows:

$$
\frac{1+\delta}{\delta}\left[P_{i}+B_{i}-c\left(Q_{i}\right)\right]
$$

Because the relational contract is similar to a sequential prisoner's dilemma game, when seeing the relational contract, the farmer will find what he/she gets if he/she declines the relational contract. If the farmer rejects the business, the he/she will obtain the value on the right-hand side of Eq. 9.

Constraint 10 represents the principal's incentive compatibility. The left-hand side of Constraint 10 indicates the present value of the utility from the relational contract for him/her. If the principal pays only a fixed price $\mathrm{P}$ observing the production of $q_{i}$ and refuses to pay the bonus $\mathrm{B}$, farmer $i$ will leaves the relational contract. As a result, the right-hand side of Eq. 10 represents the utility of the principal.

Equation 11 shows the farmer's incentive constraint in a relational contract. The left-hand side of the equation expresses the present value of the farmer's utility resulting from the adherence to the relational contract. If the farmer reduces his level of effort to reduce costs, he will obtain $[P-c(\bar{q})]$, and the principal does not pay the bonus B after verifying this situation. Therefore, B was removed from the right-hand side. If the relational contract does not hold, the present value of the utility of the farmer will be $\frac{\left[\alpha u_{f}+(1-\alpha) \bar{u}\right]}{\delta}$ which results from the continued cooperation through a formal contract or termination of the cooperation and obtaining the reservation utility. The farmer participating in a relational contract will have the incentive to continue working with the principal if the incentive constraint in Eq.11 is satisfied. Formal and relational contracts differ in the sense that a formal contract is concluded for a year, and the parties formally sign the contract. However, the parties to a relational contract consider long-term interests and usually execute an informal contract for several years.

\section{RESULTS AND DISCUSSION}

In this study, three types of farmers, $i \in\{1,2,3\}$, were considered based on the cluster analysis. Cluster analysis is one of the most commonly used classification methods aiming to identify a homogenous subset of respondents and classify the respondents based on information obtained on a series of variables (MEILĂ 2003). In this study, we identified farmers with the same input consumption. To this end, we divided the input consumption into three homogenous groups based on the characteristics of the farmers. Each group defines a type of incentive-compatible offer that the principal must propose. Table 1 shows the average consumption of each input in pistachio production by various groups from the eighth year onwards.

Pistachio lacks a commercial productivity until the seventh year, obtaining productivity from the eighth year. Therefore, we collected data on the consumption of inputs from the eighth year onwards. The principal faces three groups of farmers and must offer them incentive-compatible contracts before identifying the type of farmers.

Table 2 shows the average consumption of inputs for producing one hectare of saffron for three groups of farmers. 
Table 1. Average consumption of inputs and productivity of pistachio per hectare in different groups of farmers.

\begin{tabular}{|l|l|l|l|l|l|l|c|c|}
\hline \multicolumn{1}{|c|}{ Input } & $\begin{array}{l}\text { Dry } \\
\text { pistachio } \\
\text { Group }\end{array}$ & $\begin{array}{l}\text { Pesticides } \\
(\mathrm{L})\end{array}$ & $\begin{array}{l}\text { Land } \\
\text { preparation } \\
(\mathrm{hr})\end{array}$ & $\begin{array}{l}\text { Labor } \\
\text { force } \\
(\mathrm{hrs})\end{array}$ & $\begin{array}{l}\text { Manure } \\
\text { (tons) }\end{array}$ & $\begin{array}{l}\text { Phosphate } \\
\text { fertilizer } \\
(\mathrm{bag})\end{array}$ & $\begin{array}{c}\text { Nitrate } \\
\text { fertilizer } \\
(\mathrm{bag})\end{array}$ & $\begin{array}{c}\text { Water } \\
\left(10^{3} \mathrm{~m}^{3}\right)\end{array}$ \\
\hline First Group & 815 & 15.9 & 11 & 29.35 & 27 & 15 & 8.3 & 5 \\
\hline $\begin{array}{l}\text { Second } \\
\text { Group }\end{array}$ & 785 & 15.75 & 10.92 & 27.26 & 26.1 & 14.7 & 8.2 & 5 \\
\hline Third Group & 760 & 15 & 10.4 & 25.92 & 25 & 14 & 7.8 & 5 \\
\hline
\end{tabular}

Source: research findings.

Table 2. Average consumption of inputs and productivity of saffron per hectare for different groups of farmers.

\begin{tabular}{|l|c|c|c|c|c|c|r|}
\hline \multicolumn{1}{|c|}{$\begin{array}{c}\text { Input } \\
\text { Group }\end{array}$} & $\begin{array}{c}\text { Stigma yield } \\
(\mathrm{kg})\end{array}$ & $\begin{array}{l}\text { Pesticides } \\
(\mathrm{L})\end{array}$ & $\begin{array}{l}\text { Land } \\
\text { preparation } \\
(\mathrm{hr})\end{array}$ & $\begin{array}{l}\text { Labor force } \\
(\mathrm{hrs})\end{array}$ & $\begin{array}{l}\text { Manure } \\
(\text { tons })\end{array}$ & $\begin{array}{l}\text { Nitrate } \\
\text { fertilizer } \\
(\mathrm{bag})\end{array}$ & $\begin{array}{l}\text { Water } \\
\left(10^{3} \mathrm{~m}^{3}\right)\end{array}$ \\
\hline First Group & 2.5 & 5.5 & 17.8 & 82.72 & 16.5 & 2.75 & 3.6 \\
\hline Second Group & 2.45 & 5.25 & 16.6 & 78.96 & 15.75 & 2.625 & 3.6 \\
\hline Third Group & 2.3 & 5 & 14.4 & 75.2 & 15 & 2.5 & 3.6 \\
\hline
\end{tabular}

Source: research findings.

Reservation utility $(\mathrm{ru})$ values for pistachio production from the eighth year onward and saffron in three groups of farmers were calculated for the prices of 2018 listed in Tables 3 and 4, respectively.

Table 3. Costs and incomes of pistachio farmer representatives (UD\$/ha).

\begin{tabular}{|l|c|c|c|}
\hline & Group 1 farmer & Group 2 farmer & Group 3 farmer \\
\hline Total costs & 19494.12 & 18517.99 & 17739.46 \\
\hline Sales & 21406.48 & 20512.53 & 19874.36 \\
\hline Reservation utility $(\mathrm{ru})$ & 1912.362 & 1993.112 & 2134.711 \\
\hline
\end{tabular}

Source: research findings.

Table 4. Costs and incomes of saffron farmer representatives (UD $\$ / h a)$.

\begin{tabular}{|l|c|c|c|}
\hline & Group 1 farmer & Group 2 farmer & Group 3 farmer \\
\hline Total costs & 3918.77 & 3867.94 & 3335.94 \\
\hline Sales & 5937.53 & 5937.53 & 5462.53 \\
\hline Reservation utility $(\mathrm{ru})$ & 2018.76 & 2069.11 & 2126.35 \\
\hline
\end{tabular}

Source: research findings.

We calculated the costs of chemical and non-chemical inputs using data from the STATISTICAL CENTER OF IRAN (2018) website. We collected further information through a questionnaire. Thus, the total cost for one hectare of pistachio and saffron was determined based on prices from 2018 listed in the following tables.

Saffron presents productivity numbers from the first year, and farmers do not have to wait eight years to harvest the crop, as occurs with pistachio. Therefore, we calculated the cost and income figures from the first year.

\section{The Effects of Formal and Relational Contracts on the Income and Production of Pistachio}

In this section, we analyzed the effect of formal and relational contracts on the income and production of pistachio considering three groups of farmers. To this end, we present the price and production proposed by optimization for each representative farm. To calculate the expected utility of the principal, we determined Rev. Ciênc. Agrovet., Lages, SC, Brasil (ISSN 2238-1171) 
the probability that the principal faces each type of farmer. HIDEO et al. (2012) calculated the expected utility by using the Monte Carlo simulation. In this case, the possibility of encountering a farmer type is completely random. We calculated the average price and proposed production for each group of farmers in 1000 Monte Carlo iterations by GAMS (2010). The results are presented in Table 5.

Table 5. Results of an optimal contract for pistachio.

\begin{tabular}{|l|l|l|l|l|l|c|}
\hline & \multicolumn{3}{|c|}{ Formal contract } & \multicolumn{3}{c|}{$\begin{array}{c}\text { Relational contract } \\
\text { (utility discount rate: 20\%) }\end{array}$} \\
\hline & $\begin{array}{l}\text { Suggested } \\
\text { price } \\
\text { (US\$/kg) }\end{array}$ & $\begin{array}{l}\text { Suggested } \\
\text { production } \\
\text { quantity }\end{array}$ & $\begin{array}{l}\text { Income surplus } \\
\text { (US } \$)\end{array}$ & $\begin{array}{l}\text { Suggested } \\
\text { price } \\
\text { (US\$/kg) }\end{array}$ & $\begin{array}{l}\text { Suggested } \\
\text { production } \\
\text { quantity }\end{array}$ & $\begin{array}{l}\text { Income surplus } \\
\text { (US\$) }\end{array}$ \\
\hline $\begin{array}{l}\text { Representative } \\
\text { Farm Group 1 }\end{array}$ & 34.67 & $\begin{array}{l}(1392 \mathrm{~kg}) \\
1.7 \mathrm{ha}\end{array}$ & 11909.91 & 39.66 & $\begin{array}{l}(1520 \mathrm{~kg}) \\
1.8 \mathrm{ha}\end{array}$ & 19048.84 \\
\hline $\begin{array}{l}\text { Representative } \\
\text { Farm Group 2 }\end{array}$ & 33.48 & $\begin{array}{l}(910 \mathrm{~kg}) \\
1.15 \mathrm{ha}\end{array}$ & 6703.37 & 38.00 & $\begin{array}{l}\text { (1050 kg) } \\
1.33 \mathrm{ha}\end{array}$ & 14679.79 \\
\hline $\begin{array}{l}\text { Representative } \\
\text { Farm Group 3 }\end{array}$ & 32.30 & $\begin{array}{l}(524 \mathrm{~kg}) \\
0.68 \mathrm{ha}\end{array}$ & 3238.98 & 36.57 & $\begin{array}{l}697 \mathrm{~kg}) \\
0.91 \mathrm{ha}\end{array}$ & 11256.02 \\
\hline
\end{tabular}

Source: research findings.

Accordingly, the price and production proposed in the relational contract is higher than those suggested by the formal contract. Relational contracts are usually more efficient given that they consider stronger incentives to participate in the contract for the parties to follow the agreement in a self-enforcement manner (WU 2006). In a relational contract, the parties obtain new information in the contractual environment and adapt themselves accordingly (WILLIAMSON 1985).

In both types of contracts, farmers obtain a positive income surplus by participating in the business deal. Income surplus for all three types of farms is higher in the relational contract than that of the formal contract. As discussed earlier, a formal contract is concluded only once with the farmer. In contrast, the farmer and the principal conclude the relational contract for several years. We considered the present value of the relational contract for both parties. As a result, there is a stronger motivation for the farmer to obtain a higher income with more efforts in a relational contract. Due to a stronger incentive (in this case, the farmer) to make further efforts to achieve a higher income surplus, the contract theory is also known as the incentive theory (LAFFONT \& TIROLE 1991)

The present cultivation area for the farmer representing Group 1 is 1.7 ha. A large part of the area under cultivation belongs to Ahmad Aghaei types with a sales price of 26.12 to 33.25 US\$ per kilogram. According to Table 5, the suggested price for pistachio production is 34.67 US\$ per kilogram for formal contract and 39.66 US $\$$ per kilogram for the relational contract. The production proposed by the relational contract is of $1520 \mathrm{~kg}$ equivalent, to 1.8 ha for the farmer representing Group 1. The farmer representing Group 1 should increase the cultivation area by 0.1 ha to produce $1520 \mathrm{~kg}$ pistachios per hectare. However, given that the short-term increase in the pistachio cultivation area is impossible, the farmer increases the productivity per hectare to deliver more product to the principal and earn a total income surplus of 19048.84 US\$.

The cultivation area for the farmer representing Group 2 is of 1.5 ha. Given the productivity of $910 \mathrm{~kg}$ per ha and a suggested price of 33.48 US\$ per $\mathrm{kg}$ in the formal contract, the farmer earns an income surplus of 6703.37 US\$. To this end, he must allocate 1.15 ha of his current pistachio land to the contracted production. The remaining 0.35 ha is not contracted, and the farmer can sell it on the cash market. However, the cultivation area increases in the relational contact and reaches 1.33 ha. Considering the suggested price of 38 US $\$$, the farmer earns an income surplus of 14679.79 US $\$$ by producing $1050 \mathrm{~kg}$, which is more than twice the income surplus in the formal contract.

The cultivation area for the farmer representing Group 3 is of 1.4 ha. The production proposed by the formal contract is $524 \mathrm{~kg}$, with a price of 32.30 US $\$$ per $\mathrm{kg}$, which covers a cultivated area of 0.86 ha leading to an income surplus of 3238.98 US $\$$. However, the production proposed by the relational contract is $697 \mathrm{~kg}$ with a unit price of 36.57 US\$, leading to an income surplus of 11256.02 US\$, which is more than three times the income surplus in the formal contract. The farmer participating in a relational contract cultivates 
only 0.91 ha under the contract and can sell pistachios produced from the remaining 0.5 ha in the cash market at a lower price than that in the contract.

It is noteworthy that the contract does not cover some pistachio lands of the farmers representing Groups 2 and 3, which is predictable, since, according to LAFFONT \& MARTIMORT (2002), an optimal contract offers a lower production at a lower price for low-efficiency agents than highly efficiency agents to make an incentivize more efforts. Laffont considered efficiency as the marginal cost of the agent and believes that an agent with a lower marginal cost will be more efficient. Therefore, according to the PMPcalibrated cost function for farmers representing groups 1 to 3 , one can conclude that the farmer representing group 1 is more efficient than those in groups 2 and 3 , and the farmer representing group 2 is more efficient than that in group 3 because of a lower marginal cost. Therefore, the principal offers him/her a higher production and price.

\section{The Effects of Formal and Relational Contracts on Income and Production of Saffron}

This section concerns the effect of formal and optimal contracts on the income and production of saffron in three groups of farmers. As occurs with Pistachios, we calculated the results for the optimal contract using GAMS (2010). The results are presented in Table 6.

Table 6. Results of an optimal contract for saffron.

\begin{tabular}{|l|c|l|l|l|l|c|}
\hline & \multicolumn{3}{|c|}{ Formal contract } & \multicolumn{3}{c|}{$\begin{array}{c}\text { Relational contract } \\
\text { (utility discount rate: 20\%) }\end{array}$} \\
\hline & $\begin{array}{l}\text { Suggested } \\
\text { price } \\
\text { (US\$/kg) }\end{array}$ & $\begin{array}{l}\text { Suggested } \\
\text { production } \\
\text { quantity }\end{array}$ & $\begin{array}{l}\text { Income } \\
\text { surplus (US\$) }\end{array}$ & $\begin{array}{l}\text { Suggested } \\
\text { price } \\
\text { (US\$/kg) }\end{array}$ & $\begin{array}{l}\text { Suggested } \\
\text { production } \\
\text { quantity }\end{array}$ & $\begin{array}{c}\text { Income } \\
\text { surplus (US\$) }\end{array}$ \\
\hline $\begin{array}{l}\text { Representative } \\
\text { Farm Group 1 }\end{array}$ & 2432.25 & $\begin{array}{l}(4.05 \mathrm{~kg}) \\
1.62 \mathrm{ha}\end{array}$ & 3507.18 & 3134.54 & $\begin{array}{l}(9.99 \mathrm{~kg}) \\
3.99 \mathrm{ha}\end{array}$ & 15666.31 \\
\hline $\begin{array}{l}\text { Representative } \\
\text { Farm Group 2 }\end{array}$ & 2427.02 & $\begin{array}{l}(2.85 \mathrm{~kg}) \\
1.14 \mathrm{ha}\end{array}$ & 2507.54 & 3049.04 & $\begin{array}{l}(8.87 \mathrm{~kg}) \\
3.54 \mathrm{ha}\end{array}$ & 13322.17 \\
\hline $\begin{array}{l}\text { Representative } \\
\text { Farm Group 3 }\end{array}$ & 2421.80 & $\begin{array}{l}(1.6 \mathrm{~kg}) \\
0.69 \mathrm{ha}\end{array}$ & 1554.92 & 2967.81 & $\begin{array}{l}(7.17 \mathrm{~kg}) \\
3.12 \mathrm{ha}\end{array}$ & 10891.11 \\
\hline
\end{tabular}

Source: research findings.

Accordingly, the price and production suggested by the relational contract are higher than those provided by a formal contract because of stronger incentives for participation in relational contracts. As a result, more effort is made by the farmer to earn a higher income surplus. For instance, the net income of the saffron farm for the representative of group 1 with a cultivation area of 1.2 ha and a price of 2375 US\$ per kilogram is of 2493 US $\$$ before the contract. Given the fact that the price suggested by the formal contract is $9 \%$ higher than the saffron market price, cultivation area increases from 1.2 ha to 1.62 ha leading to a net income of about 6626 US $\$$ after participation in the formal contract. If the farmer participates in a relational contract, the suggested price and production will be of 3507.184 US\$ per kg and $9.99 \mathrm{~kg}$, respectively, which results in an income surplus of 15666.31 US $\$$ for the farmer representing group 1 . The income surplus is 7.5 times the production in the absence of a contract and 2.7 times the production under the formal contract. Given the positive yield of saffron in the harvest year, the income surplus will motivate the farmer to earn a higher income by participating in a relational contract and increasing cultivation area. To achieve this income surplus through a relational contract, the farmer should increase the cultivating area to 3.99 ha.

The cultivation area of the farmer representing Group 2 is of 1 ha. The price and production suggested by the formal contract are of 2427.02 US $\$$ per $\mathrm{kg}$ and $2.85 \mathrm{~kg}$, respectively. The price and production proposed by the relational contract are of 3049.04 US $\$$ and $8.87 \mathrm{~kg}$, respectively. These values are equivalent to a cultivation area of $3.54 \mathrm{ha}$. In the case of a formal contract, the income surplus is of 2507.54 US\$, which is 2.42 times that obtained without participating in a formal contract. If the farmer representing Group 2 accepts a relational contract, he earns an income surplus of 13322.17 US\$ which is 4.7 times that obtained without participating in a relational contract. It is noteworthy that the farmer should increase the cultivating area from 1 ha to 1.14 ha in the formal contract and to 3.49 ha in the relational contract to achieve this income surplus. Saffron is profitable in the first year of cultivation, so the farmer can increase the cultivation area to increase the income surplus. 
The cultivation area for the farmer representing Group 3 is of 0.8 ha. The income surplus for the formal and relational contracts equals 1554.92 and 10891.11 US $\$$, which are respectively 2 and 6.4 times higher than the income surplus in the absence of formal and relational contracts. Note that the production suggested by the formal contract for the farmer representing Group 3 is lower than that in the absence of a formal contract. However, the income surplus is higher in this case because of a higher price suggested by the formal contract. The production suggested by the relational contract is $7.17 \mathrm{~kg}$, equivalent to $3.12 \mathrm{ha}$. Therefore, the farmer representing Group 3 must make efforts to increase the cultivation area to achieve income surplus.

The analysis provided by LAFFONT \& MARTIMORT (2002) applies to the marginal cost of saffron producers. The farmer with a lower marginal cost works more efficiently. Therefore, the production and price suggested for the farmer representing Group 1 are higher than those in Group 2 and 3 . The corresponding values for the farmer representing Group 2 are higher than that in Group 3.

\section{The Risk of Farmers before and after the Contract}

Mean-variance is one of the methods for considering the risks of agricultural activities. Based on the expected revenue-variance method, farmers are risk-averse, and the farmer's risk is estimated through revenue variance (ANDERSON et al. 1977). Triangular distribution can be used to determine the subjective mean and variance of farmers. The triangular distribution is a continuous distribution and requires three risk variables (e.g., yield or price of crops) including the minimum (a), maximum (b), and the most probable (m) value of the risk variable (ANDERSON et al. 1977). We calculated the mean $E(x)$ and variance $V(x)$ for the triangular distribution using Eqs. 14 and 15, respectively:

$$
\begin{aligned}
& E(x)=(a+b+m) / 3 \\
& V(x)=\left[(b-a)^{2}+(m-a)(m-b) / 18\right]
\end{aligned}
$$

We used the time series data and various pistachio and saffron production values, shown in Table 7 , to calculate the subjective mean and variance of gross margin of pistachio and saffron producers.

Table 7. Price and annual production of one hectare of pistachio and saffron.

\begin{tabular}{|l|c|l|l|l|c|c|}
\hline Crop year & $\begin{array}{l}\text { Pistachio } \\
\text { yield }(\mathrm{kg} / \mathrm{ha})\end{array}$ & $\begin{array}{l}\text { Saffron } \\
\text { yield } \\
(\mathrm{kg} / \mathrm{ha})\end{array}$ & $\begin{array}{l}\text { Pistachio } \\
\text { price } \\
(\mathrm{US} \$ / \mathrm{kg})\end{array}$ & $\begin{array}{l}\text { Saffron } \\
\text { price } \\
(\mathrm{US} \$ / \mathrm{kg})\end{array}$ & $\begin{array}{l}\text { Pistachio } \\
\text { gross margin } \\
(\mathrm{US} \$ / \mathrm{ha})\end{array}$ & $\begin{array}{l}\text { Saffron gross } \\
\text { margin } \\
(\mathrm{US} \$ / \mathrm{ha})\end{array}$ \\
\hline 2008 & 911.2 & 1.76 & 5.44 & 1355.35 & 4958 & 2385.42 \\
\hline 2009 & 988.4 & 2.64 & 6.86 & 1353.65 & 6858.55 & 3573.64 \\
\hline 2010 & 719.2 & 3.76 & 7.30 & 1793.17 & 5254.17 & 6742.33 \\
\hline 2011 & 637.6 & 3.76 & 7.47 & 1959.27 & 4769.02 & 7366.86 \\
\hline 2012 & 782.4 & 3.76 & 24.46 & 1754.54 & 19145.19 & 6597.07 \\
\hline 2013 & 1138.4 & 3.68 & 12.90 & 3295.52 & 14696.74 & 12127.53 \\
\hline 2014 & 1188.8 & 3.59 & 12.74 & 3364.03 & 15146.29 & 12083.62 \\
\hline 2015 & 1181.6 & 3.56 & 11.53 & 3049.02 & 13632.3 & 10854.53 \\
\hline 2016 & 1198.4 & 4.08 & 11.02 & 3000.99 & 13208.08 & 12244.05 \\
\hline 2017 & 717.6 & 3.28 & 13.79 & 2839.02 & 9902.78 & 9311.99 \\
\hline 2018 & 80 & 1.6 & 38.00 & 2910.08 & 3040.01 & 4656.14 \\
\hline
\end{tabular}

Source: Ministry of Agriculture Jihad website.

Table 8 shows the subjective mean and standard deviation of farmers on the gross margin of pistachio and saffron.

To compare the risk associated with the gross margin after the contract, we calculated the mean and standard deviations of the gross margins for pistachio and saffron suggested by the relational contract for different discount rates. Table 9 shows the results. 
Table 8. Subjective mean and variance of farmers determined using the triangular distribution method.

\begin{tabular}{|c|c|c|c|c|c|}
\hline Product & \multicolumn{5}{|c|}{ Gross margin } \\
\hline & a (US\$/ha) & b (US\$/ha) & m (US\$/ha) & $\begin{array}{c}\text { Mean } \\
\text { (US\$/ha) }\end{array}$ & $\begin{array}{l}\text { Standard } \\
\text { deviation }\end{array}$ \\
\hline Pistachio & 3040.019 & 19145.19 & 10055.56 & 10746.92 & 255833753 \\
\hline Saffron & 2385.426 & 12244.05 & 7994.838 & 7541.439 & 95868348 \\
\hline
\end{tabular}

Source: research findings.

Table 9. Mean and variance of the gross margin of the relational contract for pistachio and saffron.

\begin{tabular}{|c|l|c|c|}
\hline Product & & Standard Deviation & Mean (US\$/ha) \\
\hline \multirow{3}{*}{ Pistachio } & Farm representing Group 1 & 15847263 & 13152.12 \\
\cline { 2 - 4 } & Farm representing Group 2 & 12589743 & 12226.23 \\
\cline { 2 - 4 } & Farm representing Group 3 & 5847963 & 11856.21 \\
\hline \multirow{3}{*}{ Saffron } & Farm representing Group 1 & 702158 & 7952.42 \\
\cline { 2 - 4 } & Farm representing Group 2 & 689524 & 7812.97 \\
\cline { 2 - 4 } & Farm representing Group 3 & 602548 & 7743.21 \\
\hline
\end{tabular}

Source: research findings.

According to the results presented in Tables 8 and 9, the standard deviation of the gross margin of the relational contract is lower than non-contract production. The mean production expected under a relational contract is higher than that under no contract. According to the results, the farmer participating in the contract experiences less volatility in gross margin and earn more revenues. These results are consistent with other studies on contract farming. The farmer participating in contract farming are incentivized to make more effort for a larger production and income surplus. At the same time, price fluctuations are lower if the price is specified.

\section{CONCLUSION}

Contract farming is rapidly spreading in developing countries partly due to the need of domestic and foreign stores for more modernized supply chains, as well as the growth of quality assurance standards (HENSON et al. 2005, SWINNEN \& MAERTENS 2007). Recent studies on contract farming have focused on farmers' participation, contractual relationships, and measurement of the welfare effects of contracts. This study evaluated the impact of formal and relational contracts on the income and risk of pistachio and saffron producers in the Yazd Province in central Iran. Because contract farming has received little emphasis in Iran, the cost function of the farmers was calibrated by using positive mathematical programming (PMP) after determining three groups of farmers with different input consumption and yield per hectare.

Subsequently, we reviewed the formal and relational contracts and presented the results on optimization of both contracts. We modeled both types of contracts according to incentive constraints on the participation of the farmer and principal. According to the results, the production and price suggested by the relational contract were higher than those suggested by the formal contract. According to WU (2014), stronger incentive constraints of relational contracts, which both parties repeatedly sign over several years, increase the parties' efforts to respect the terms of the contract. Therefore, the farmer's efforts to achieve a higher income surpluse lead to a higher production and, consequently, a higher price, which in turn maximizes the present value of the farmer's utility. We calculated the farmer's income and variance according to the time series of pistachio and saffron and compared them with the mean and variance derived from the relational contract. We found that the farmer who participated in the relational contract experienced less volatility and risks while earning more revenues. This study also presented two policymaking proposals. First, to support the farmers, the policymaker must consider the development of contract farming. The farmers should be acquainted with these contracts through the agricultural promotion agencies to increase their participation in contract farming. Second, the government should encourage agribusiness companies to participate in contract farming. For instance, by creating proper structures, facilitating access to credits, and 
providing other incentives to investment, the government should pave the way for agribusiness companies to enter such contracts. The juridical and legal principles of the contracts should also be considered by policymakers under the national conditions. Finally, we suggests further studies. First, given the fact that Iran is suffering from a drought crisis, researchers should explore the use of contracts to develop low-water crop production in different parts of Iran. Second, other types of cost functions are recommended for modeling the optimal contract. Since, in most cases, it is difficult to distinguish farmer types in terms of input consumption and yield, the type of farmer can be continuously considered to design an optimal contract for the farmers.

\section{REFERENCES}

ABEBE GK et al. 2013. Contract farming configuration: Smallholders' preferences for contract design attributes. Food Policy 40: 14-24.

ANDERSON JR et al. 1980. Agricultural Decision Analysis. Ames: lowa State University Press. 344p.

BARRETT CB. 2008. Smallholder market participation: Concepts and evidence from eastern and southern Africa. Food Policy 33: 299-317.

BARRETT CB et al. 2012. Smallholder Participation in Contract Farming: Comparative Evidence from Five Countries. World Development 40: 715-730.

BELLEMARE MF. 2012. As You Sow, So Shall You Reap: The Welfare Impacts of Contract Farming. World Development 40: 1418-1434.

BIJMAN JR et al. 2016. Cooperatives, Economic Democratization and Rural Development. Cheltenham: Edward Elgar Publishing. 320p.

DASGUPTA PS \& HEAL GM. 1980. Economic Theory and Exhaustible Resources. Cambridge: Cambridge University Press. 516p.

DEWATRIPONT M \& BOLTON P. 2005. Contract Theory. Massachusetts: MIT Press. 724p.

DINA UD. 1997. Public and Private Agricultural Extension: Partners or Rivals? The World Bank Research Observer 12: 203-224.

FAFCHAMPS M. 1992. Cash Crop Production, Food Price Volatility, and Rural Market Integration in the Third World. American Journal of Agricultural Economics 74: 90-99.

GAMS. 2010. A User's Guide. Washington: GAMS Development Corporation. 293p.

GUO HR et al. 2005. Contract Farming in China: Supply Chain or Ball and Chain? Proceedings of the Minnesota International Economic Development Conference. Minnesota: University of Minnesota.

HALAC M. 2012. Relational Contracts and the Value of Relationships. American Economic Review 102: 750-779.

HENSON SO et al. 2005. Private food safety and quality standards for fresh produce exporters: The case of Hortico Agrisystems, Zimbabwe. Food Policy 30: 371-384.

HIDEO H et al. 2012. Contract Theory: A Programming-Model Approach. GRIPS Discussion Papers: 10-34.

HOWITT RE. 1995. Positive Mathematical Programming. American Journal of Agricultural Economics 77: 329-342.

IRAN MINISTRY OF AGRICULTURE JIHAD. 2017. Agricultural statistics of the crop year of 2016-2017. Tehran: Institution of Jihad Press. 102p.

KEY N \& RUNSTEN D. 1999. Contract Farming, Smallholders, and Rural Development in Latin America: The Organization of Agroprocessing Firms and the Scale of Outgrower Production. World Development 27: 381-401.

KIRSTEN J \& SARTORIUS K. 2002. Linking agribusiness and small-scale farmers in developing countries: Is there a new role for contract farming? Development Southern Africa 19: 503-529.

KOVÁCS K. 2018. Managerial Challenges in Hungarian Agricultural Enterprises. In: BRYŁA P. (Ed.). Managing Agricultural Enterprises: Exploring Profitability and Best Practice in Central Europe. Cham: Springer International Publishing. p.225-239.

LAFFONT JJ \& MARTIMORT D. 2002. The Theory of Incentive: The Principal-Agent Model. Princeton: Princeton University Press. 440p.

LAFFONT JJ \& TIROLE J. 1991. The Politics of Government Decision-Making: A Theory of Regulatory Capture. The Quarterly Journal of Economics 106: 1089-1127.

LAJILI K et al. 1997. Farmers' Preferences for Crop Contracts. Journal of Agricultural and Resource Economics 22: 264280.

LEEGOMONCHAI P \& VUKINA T. 2005. Dynamic Incentives and Agent Discrimination in Broiler Production Tournaments. Journal of Economics \& Management Strategy 14: 849-877.

LEVIN J. 2003. Relational Incentive Contracts. The American Economic Review 93: 835-857.

LITTLE PD \& WATTS M. 1994. Living under contract: contract farming and agrarian transformation in Sub-Saharan Africa. Madison: University of Wisconsin Press. 288p.

LYSON TA. 2012. Civic Agriculture: Reconnecting Farm, Food, and Community. Medford: Tufts University Press. 160p.

MACLEOD WB. 2007. Reputations, Relationships, and Contract Enforcement. Journal of Economic Literature 45: 595628.

Rev. Ciênc. Agrovet., Lages, SC, Brasil (ISSN 2238-1171) 
MARGLIN SA. 1963. The Social Rate of Discount and The Optimal Rate of Investment. The Quarterly Journal of Economics 77: 95-111.

MEILĂ M. 2003. Comparing Clusterings by the Variation of Information. In: SCHÖLKOPF B \& WARMUTH MK. (Eds). Learning Theory and Kernel Machines. Berlin: Springer.

MINTEN B et al. 2009. Global Retail Chains and Poor Farmers: Evidence from Madagascar. World Development 37 : 1728-1741.

MIYATA S et al. 2009. Impact of Contract Farming on Income: Linking Small Farmers, Packers, and Supermarkets in China. World Development 37: 1781-1790.

MURRAY EV. 2014. Risk Management in Rural Financial Cooperatives. Bombaim: National Bank for Agriculture \& Rural Development.

OSKONEZHAD M. 1993. Engineering Economics, Economic Assessment of Industrial Projects. Teerã: Amir Kabir University of Technology Press.

PORTER G \& PHILLIPS-HOWARD K. 1997a. Contract Farming in South Africa: A Case Study from Kwazulu-Natal. Geography 82: 38-44.

PORTER G \& PHILLIPS-HOWARD K. 1997b. Comparing contracts: An evaluation of contract farming schemes in Africa. World Development 25: 227-238.

REHBER E. 2007. Contract Farming: Theory And Practice. Hyderabad: ICFAI University Press. 181p.

SINGH S. 2002. Multi-national corporations and agricultural development: a study of contract farming in the Indian Punjab. Journal of International Development 14: 181-194.

STATISTICAL CENTER OF IRAN. 2018. Data and statistical information. Disponível em: https://www.amar.org.ir. Accessed on: 05 April. 2019.

SWINNEN JFM \& MAERTENS M. 2007. Globalization, privatization, and vertical coordination in food value chains in developing and transition countries. Agricultural Economics 37: 89-102.

WANG HH et al. 2011. Is contract farming a risk management instrument for Chinese farmers?: Evidence from a survey of vegetable farmers in Shandong. China Agricultural Economic Review 3: 489-505.

WARNING M \& KEY N. 2002. The Social Performance and Distributional Consequences of Contract Farming: An Equilibrium Analysis of the Arachide de Bouche Program in Senegal. World Development 30: 255-263.

WILLIAMSON OE. 1985. The economic institutions of capitalism: firms, markets, relational contracting. New York: The Free Press. 450p.

WU SY. 2006. Contract theory and agricultural policy analysis: a discussion and survey of recent developments. Australian Journal of Agricultural and Resource Economics 50: 490-509.

WU SY. 2014. Adapting Contract Theory to Fit Contract Farming. American Journal of Agricultural Economics 96: 12411256.

WU SY \& ROE B. 2007. Contract Enforcement, Social Efficiency, and Distribution: Some Experimental Evidence. American Journal of Agricultural Economics 89: 243-258. 